\title{
Analysis of the Attitude of a Geological Setting in Raising up Critical Stability Conditions in Slopes: a Methodological Approach
}

\author{
M. G. ANGELI, ${ }^{*}$ H. NAKAMURA, ${ }^{* *}$ R. TSUNAKI, ${ }^{* * *}$ \\ K. NITTA, ${ }^{* * *}$ K. OKUDA, ${ }^{* * *}$
}

要 旨

イタリア中央部のいくつかの粘性土地すべりにおいて地すべり土塊の下部で高い間隙水圧を示す部分がある ことがこれまでに報告されている。これは土塊の透水性が深度により違っているためと考えられた。

このようなことが別の地質状況のもとでああてはまるかを調べるため, 日本の新潟県の第三系の地すべりにつ いて差分法による浸透流解析を行った。文献及び透水試験結果を参考にすべり面付近に高い透水係数を与え, そ の高透水層の端が地表に出る場合, また初生すべりによる分断及び崩土による埋没により地表に出ない場合を考 えて, 色々なケースについて解析を行い, 各々のケースの流線網を得た。そしてこの結果からすべり面の間隙水 圧の分布を求め静水圧と比較した。また最も限界的な斜面の安定度を示すケースで安定度の逆解析を行った。 すべり面に沿う間隙水圧の実測値がないため計算値との比較はできないが, これらの解析の結果, 現位置の透 水試験で得られた深度により異なる透水係数を与えた場合, イタリアの例と同様に斜面の下部で高い間隙水圧を 示すことがわかった。また逆解析の結果, 安定計算を行うときすべり土塊全体として行うよりも, 下部の間隙水 圧の高い部分を別ブロックとして考えて行ったほうが現実的であるという結果が得られた。このことは進行性の すべりは斜面の下方から発生することを示唆している。さらにそこで調べた事例では, すべり土塊を全体として そして静水圧による間隙水圧が作用するとして逆解析を行うと，せん断強度を過大に評価することになってしま うという結果も得られた。

\section{Introduction}

Geological and geotechnical studies carried out in connection with the stability of some clay slopes of Central Italy revealed high pore pressure fields in the lower parts of the landslide bodies (Angeli and Tonnetti, 1984; Angeli and others, 1984; Angeli and Tonnetti, 1986; Tonnetti and Angeli, 1984).

The reason for this behaviour was attributed to variation with depth of the measured hydraulic conductivities (coefficients of permeability).

In order to check this hypothesis a numerical model of the groundwater-flow pattern of these slopes was developed (Angeli, 1985). Analysis based on this model gave results which confirmed that variation with depth of hydraulic conductivity (cofficient of permeability) may lead to high pore water pressures, often in excess of hydrostatic values, along the lower part of the slip surface. Moreover these pore water pressures were in agreement with observed values for four landslides. It is significant that these landslides belong to the same geological and climatic setting, but were spread within a large region.

The aim of the work reported in this present paper was to investigate if similar factors influenced landslide development in a different geological environment. The opportunity for such work presented itself when the first author worked in Japan during the last three months of 1988.

Some large landslides in Japan (e.g. the Sarukuyoji landslide, in Niigata Prefecture; Yamade landslide, in Fukushima Prefecture, etc.) were found to have in the lower parts very large measured pore pressures (Fig. 1), exceeding the hydrostatic pore pressure distribution. But

\footnotetext{
* IRPI, National Research Council, Perugia, Italy

** Head of Landslide Division, PWRI, Tsukuba

*** PWRI, Tsukuba
} 
data concerning the variation of permeability with depth were lacking.

In some other landslides, data concerning variation of permeability with depth were available, but in contrast to the other slopes mentioned, there were on pore pressure measurements for these lanaslides.

This latter group constituted the sample the authors were looking for.

Therefore, the present work deals with a large sample of 24 landslides (Fig. 2). They belong to the same geological setting and climatic environment, which is the territory of Niigata Prefecture $\left(12,000 \mathrm{~km}^{2}\right)$.

Like the small Italian sample (four landslides), all these Japanese landslides of the present time are exclusively affected by hydrological factors. In other words they do not seem to be caused by seismic activity or the intervention of man, but only by rainfall and snow precipitations.

Almost everywhere the stratigraphic succession of

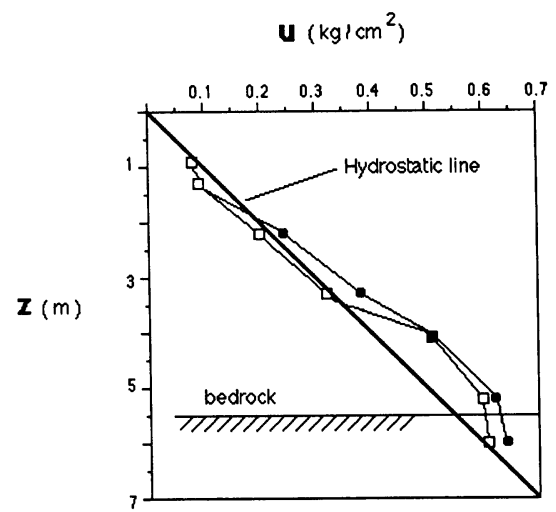

Figure 1. Pore pressure distribution vs. depth (Sarukuyoji landslide) showing pressures in excess of hydrostatic especially at depth greater than $4 \mathrm{~m}$ (measurements taken by means of different electric piezometers in two different borehole locations) the slopes is constituted of an uppermost layer of colluvium (5-15 $\mathrm{m}$ in thickness), a weathered and/or fractured intermediate layer of rock (5$10 \mathrm{~m}$ in thickness) and sound bedrock below that layer (Fig. 3). The intermediate layer of rock, formed of mudstone or andesitic lava or tuff breccia, is the result of the weathering and fracture processes affecting the sound rocks below.

The attitude of strata is approximately dip-slope and their dip ranges between few degrees to 20 degrees.

The sliding occurs generally on slip surfaces located within the middle leyer; however often failures occur within the colluvium or at the interface between colluvium and weathered rock.

In fact, inside the top layer of colluvium the presence of continuous lenses of wethered clays facilitates the process of slip surface formation.

From the geological point of view these rocks belong to the Tertiary Age, and specifically to a period including late Miocene and Pleistocene.

A large amount of data about these landslides were provided by the Landslide Division of

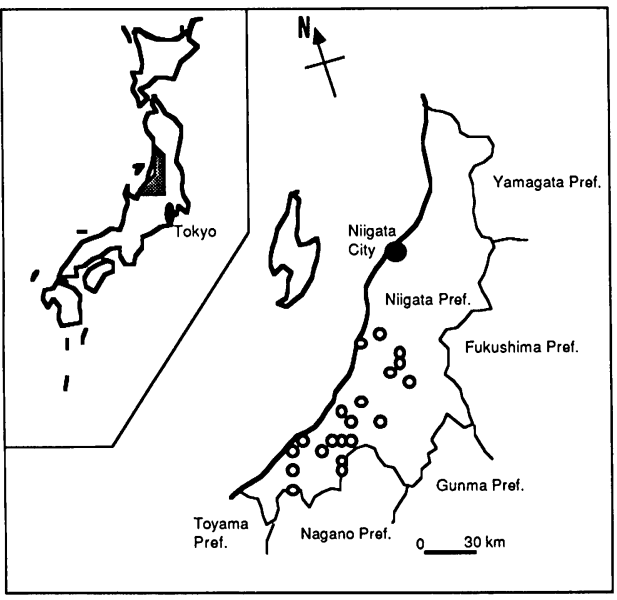

Figure 2. Location map of landslides examinedNiigata Prefecture

(Note: Several samples are picked up from the same landslide area.)

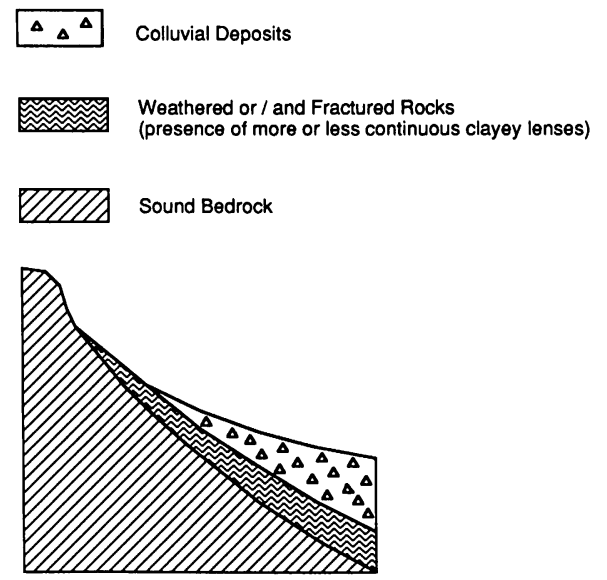

Figure 3. Simplified stratigraphic pattern of slopes 
Niigata prefecture. As previously stated, the vertical profiles of permeability vs. depth, obtained by means of pumping tests, were also available.

The analysis of theve profiles revealed that the magnitudes of the coefficient of permeability were relatively high at certain depths consistent with the slip surface location.

Therefore, it was decided to use a numerical model to study the influence of such variation in coefficient of permeability on the pore water pressures. As a starting point it was considered sufficient

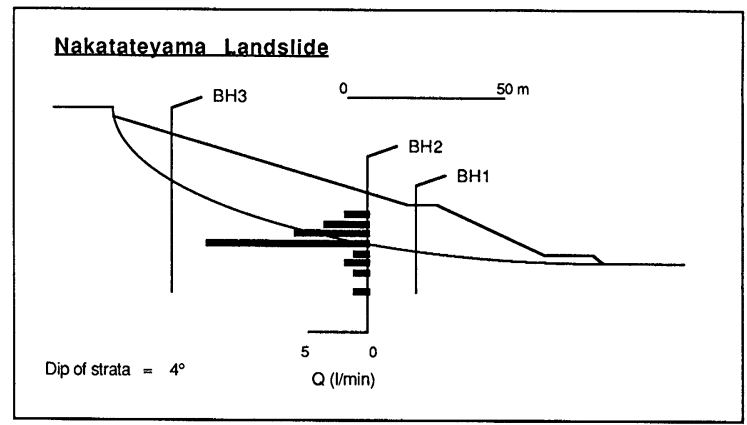

Figure 4. Cross section of Nakatateyama landslide showing borehole locations and vertical profile of hydraulic conductivities at the location of $\mathrm{BH} 2$ and strate dipping to study one of these landslides because they had so many similar characteristics. The landslide selected was Nakatateyama landslide, a cross section of which is shown in figure 4 .

\section{Climatic outline}

For its geographic position facing the Japan sea, Niigata Prefecture has got a climate which is strongly affected by the humidity, evaporation in summer and by the Siberian cold air currents during the winter season. During winter abundant snow precipitations occur with snow cover depths of several meters.

In addition, the region is affected by rainfall precipitations from November to December and by long-term rainfall in July: the yearly average rainfall often exceeding $2,000 \mathrm{~mm}$.

The distribution of all these severe climate conditions, all over the year, has an adverse effect on the stability of slopes and leads to the development of landslides.

Figure 5 shows the mean yearly distribution of the frequency of the landslide phenomena in Niigata Prefecture (from 1941 to 1973) in relationship with the climatic conditions observed in Takada City.

\section{Geological sttting}

In the territory of Niigata Prefecture the slopes are formed of both sedimentary rocks and volcanic or pyroclastic ones, dating from the Tertiary Age. In particular the landslide sites belong to a period including both Late Miocene and Pliocene.

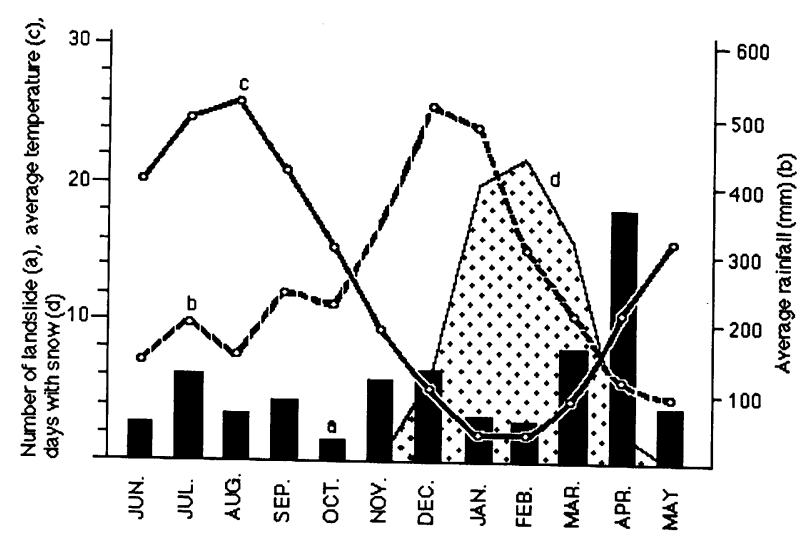

Figure 5. Monthly average frequency of landslide (a) Niigata Prefecture, for the period 1941-1973, and climatic conditions in Takada City given as follows: monthly average rainfall height in $\mathrm{mm}$ (b), monthly average temperature in ${ }^{\circ} \mathrm{C}$ (c) and average number of days per month with snow depth over 50 $\mathrm{cm}$ (d)

During that period it was particularly warm and sea level went up all over the world. In the northeastern part of Japan which includes the territory of Niigata Prefecture, there was also a very strong tectonic and volcanic activity.

As a result, we can now find almost everywhere not only a great volume of volcanic and pyroclastic rocks, but also a great volume of sedimentary rocks (mudstone and sandstone) deposited in the subduction zone.

\section{Hydrogeological and geotechnical characteristics of slopes}

Due to the alternation of sedimen- 
tary and volcanic rocks combined with the weathering and fracture processes which affect some parts of the slopes, the spatial distribution of the hydrogeological characteristics of the slopes is strongly non-homogeneous.

In the slopes examined the hydraulic conductivity values may range from $10^{-5}$ to $10^{-4} \mathrm{~cm} /$ $\mathrm{s}$ in the covers, $10^{-3}$ to $10^{-2} \mathrm{~cm} / \mathrm{s}$ in strongly fractured rocks, whereas they are always below $10^{-5} \mathrm{~cm} / \mathrm{s}$ in the bedrock.

In multilayered slopes the ratio between the hydraulic conductivity values in two contiguous layers could be as high as 1,000 .

Under these conditions and considering the presence of vertical fissures or cracks, the possibility of short-term phenomena of confined subsurface flow in the higher permeability layers increases. As a consequence the possibility of landslides influenced both by short-term and long-term precipitations also increases.

Moreover, interbedded thin clay layers with low shear resistance create the conditions for the formation of slip surfaces. Laboratory tests carried out on several clay asamples to obtain the residual shear strength, gave values distributed in quite a uniform way ranging from $7^{\circ}$ to $27^{\circ}$. According to casagrande classification these clays are of middle to high plasticty.

\section{Numerical model}

The model utilized for analysing the groundwater-flow pattern in slopes is based on a finite difference solution of the equation of the steady flow of an incompressible fluid through homogeneous and anisotropic porous media, with rigigid skeleton (Angeli, 1985).

It takes into consideration up to 3 superposed media at different permeability, indicated by the letters $\mathrm{A}, \mathrm{B}$ and $\mathrm{C}$ in the idealised slope model of figure $6 \mathrm{a}$. A and $\mathrm{B}$ media are homogeneous and isotropic, whereas $\mathrm{C}$ can be also treated as an anisotropic medium.

In order to put in direct contact $\mathrm{A}$ and $\mathrm{C}$ media to represent certain field situations the model has been modified. The modification has been introduced to simulate the cut off of the central layer (B) due to a first-time landslide movement (Fig. 6b) or to an accumulation of colluvial deposits at the foot of the slope (Fig. 6c).

The boundary conditions assumed are shown in figure $6 \mathrm{a}$. Along the contour 1$2-3-4, h=z$ corresponds to the absence of fluctuation in groundwater table (steady flow conditions and groundwater table coinciding with the ground surface); $\mathrm{q}_{\mathrm{x}}=0$ (along contour lines 1-6 and 4-5) and $\mathrm{q}_{z}=$ 0 (along the base contour line 5-6) correspond to a zero velue of flux. In other words the external boundary of the region analysed is assumed to be a flow line.

The model is very flexible and it is possible to introduce many different distributions of hydraulic conductivity.

\section{Analysis of the critical hydraulic conditions in Nakatateyama landslide}

Before going through the actual analysis performed it is useful to make some preliminary observations.

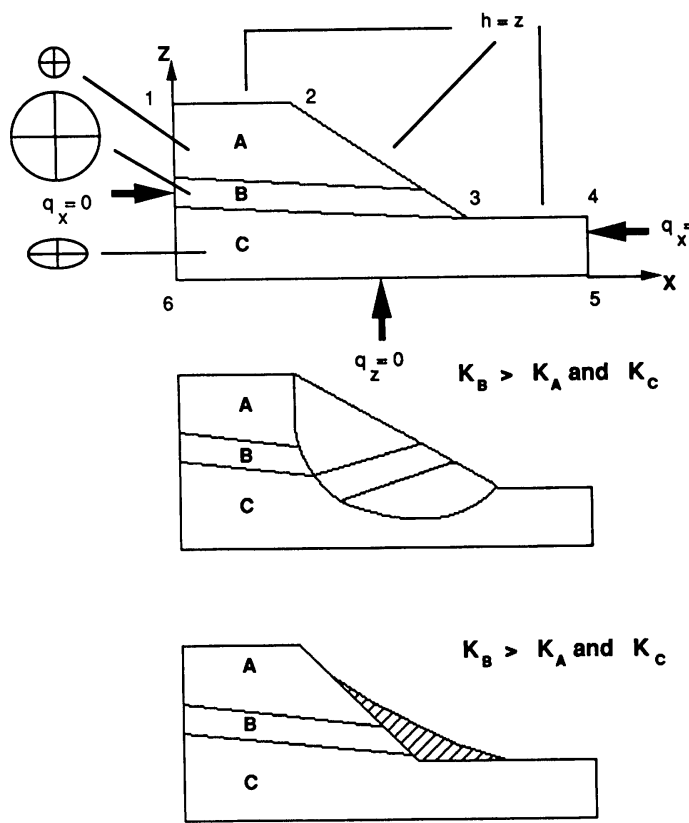

(a

Figure 6. Idealized diagrams for a slope with three soil layers having different coefficients of permeability (layer $\mathrm{A}$ and $B$ are isotropic with respect to permeability and layer $C$ is anisotropic) showing: a) hydraulic boundary conditions; b) cut off of water outlet from high petmeability layer due to a first-time landslide; c) cut off of water outlet from high permeability layer due to an accumlation of colluvial deposits 
Firstly, in the Nakatateyama landslide pore pressure measurements had not been made before the completion of the drainage control works. Therefore one would not be able to make a direct comparison between observed values, not affected by control works, and the calculated ones. In other words, it was impossible to follow the usual procedure (which the first author followed for the studies of Italian landslides mentioned in the Introduction), that is to compare data coming from any kind of computation procedure with in situ measuements. Therefore, the following procedure of analysis was made: in the slope more than one distribution (with depth) of hydraulic conductivity was assumed; then, the corresponding values of pore pressure from analyses used to generate flow-nets. The one which was most critical for the stability of the slope was then selected.

Secondly, the vertical profiles of the hydraulic conductivity were not available along the whole body of the landslide, but only in one borehole location (Fig. 4). Therefore, the vertical profile of permeability measured in the middle of Nakatateyama slope was utilized for the whole slope in accordance with the dip of strata. Similar procedure was adopted for the distributions used for other analyses.

Third, the vertical profiles of permeability utilized in the computations, besides the one coming from the pumping tests carried out in Nakatateyama slope, were realistically assumed, taking into account the values found in the scientific papers, dealing with the other landslides examined. In this sense, the different cases of permeability distributions assumed in Nakdtateyama slope are not hypothetical but quite realistic. These distributions can be considered as a range of equally possible cases. The application of the numerical model to every single distribution, provided for a corresponding range of possible flow-nets or, in other words, of possible pore pressure distributions on the slip surface.

The analysis was started taking into account 10 different but reasonable vertical distributions of hydraulic conductivity in the landslide body, including the measured one which was based on pumping tests.

All the distributions (except $\mathrm{A}$ and $\mathrm{AA}$ in figure 7 ) simulated the presence of a higher permeability layer located at depth consistent with the sliding surface. However, they strongly differed in the value of the hydraulic conductivity ratio and in the length assigned to the layer of higher permeability.

Different lengths were assigned-as previously stated-to this higher permeability layer to simulate the cut off of the groundwater outlet, as a consequence of a landslide mass dislocation or/and accumulation (Figs. $6 \mathrm{~b}$ and $6 \mathrm{c}$ ).

The 10 different flow nets coming from numerical analysis are shown in figure 7 and simply indicated by the letters A, AA, B, BB, C, CC, D, DD, E, EE. They provided for as many pore pressure distributions along the slip surface.

In figure 8 some of these distributions together with the hydrostatic one are shown.

The solid line represents this hydrostatic distribution which is the reference distribution, whereas the dotted line represents $B$ distribution.

It is significant that this latter distribution, coming from the flow net indicated with $\mathrm{B}$, was calculated taking into account the real values of permeability obtained by in situ permeability tests. It is the most critical for the lower part of the slip surface.

Moreover, on the basis of this particular case study one could explain the high pore pressure field found in the lower part of many slopes to which reference has already been made in the Introduction.

\section{Stability analysis}

Due to the lack of measured pore pressures the stability analysis of the landslide was done utilizing the calculated pressure distributions along the slip surface.

However all the calculated distributions were not utilized. In fact, since the B distribution is the most critical for the lower part of the slip surface and since it was based on the in situ measured hydraulic conductivities, a back analysis of stability was performed taking into account this B distribution and the hydrostatic one as datum-distribution. 
But, as was the case with the analysis of stability of the Italian landslides, a problem regarding the modalities of analysis arose. In the studies of Itlian landslides, the usual approach of analysis was found to have some limitations if the landslide body was long in ralation to depth and, in particular, if high pore pressures were localized in the lower part of the long slip surface.

The problem is that the usual stability analyses take into account the whole landslide body, considering it as an ideal coherent mass and without paying a particular attention to the most critical parts inside it. As a result one could obtain only an average value of the

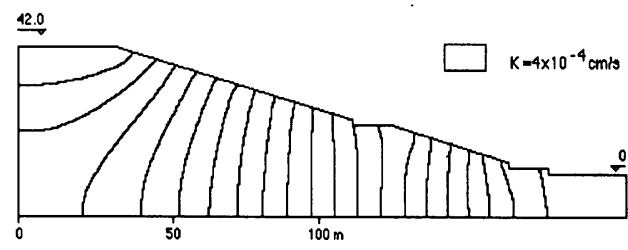

Case A : uniform hydraulic conductivity distribution.

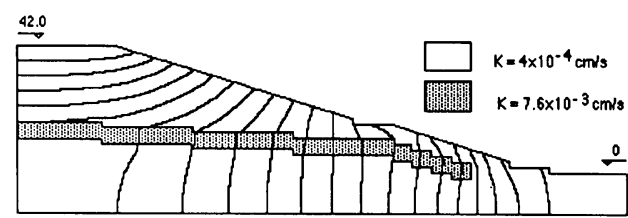

Case B: measured hydraulic conductivity distribution.

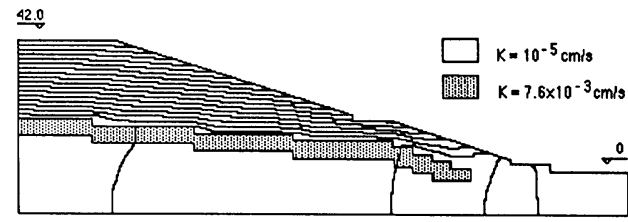

Case C: assumed hydraulic conductivity distribution.

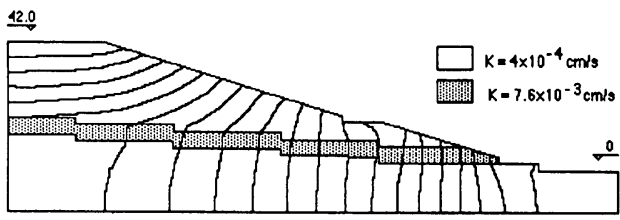

Case D: measured hydraulic conductivity distribution and continuous intermediate layer.

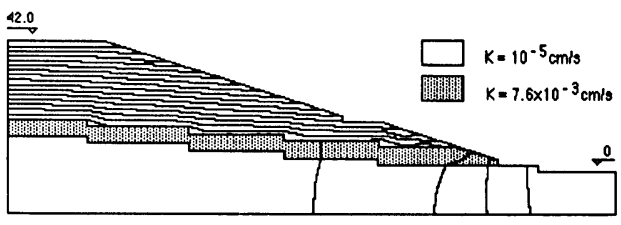

Case E: assumed hydraulic conductivity distribution and continuous intermediate layer.

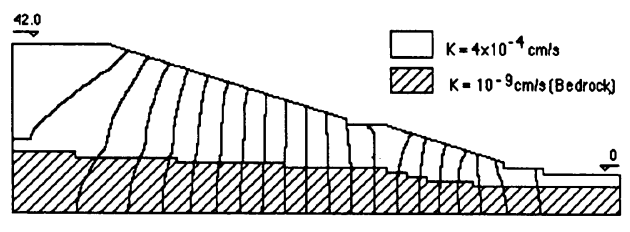

Case AA: uniform hydraulic conductivity distribution and presence of higher elevation bedrock.

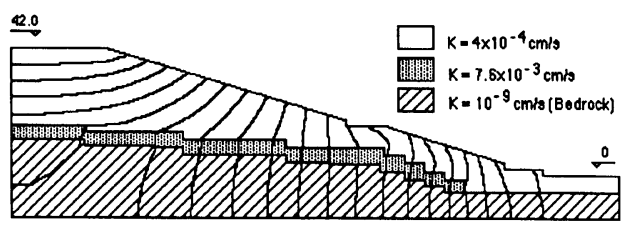

Case BB: measured hydraulic conductivity distribution and presence of higher elevation bedrock.

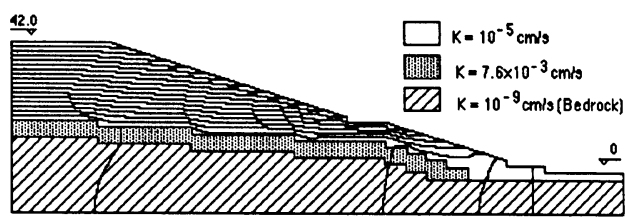

Case CC: assumed hydraulic conductivity distribution and presence of higher elevation bedrock.

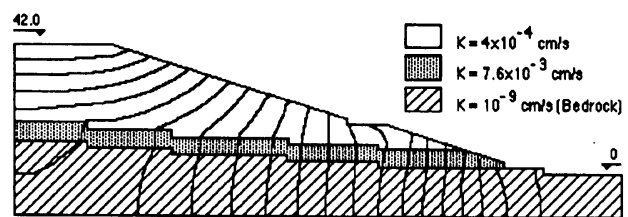

Case DD: measured hydraulic conductivity distribution, continuous intermediate layer and presence of higher elevation bedrock.

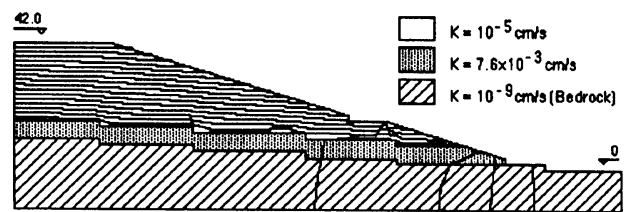

Case EE: assumed hydraulic conductivity distribution, continuous intermediate layer and presence of higher elevation bedrock.

Figure 7. Flow nets based on the developed computer model (interval of equipotential lines is $2 \mathrm{~m}$ ) 


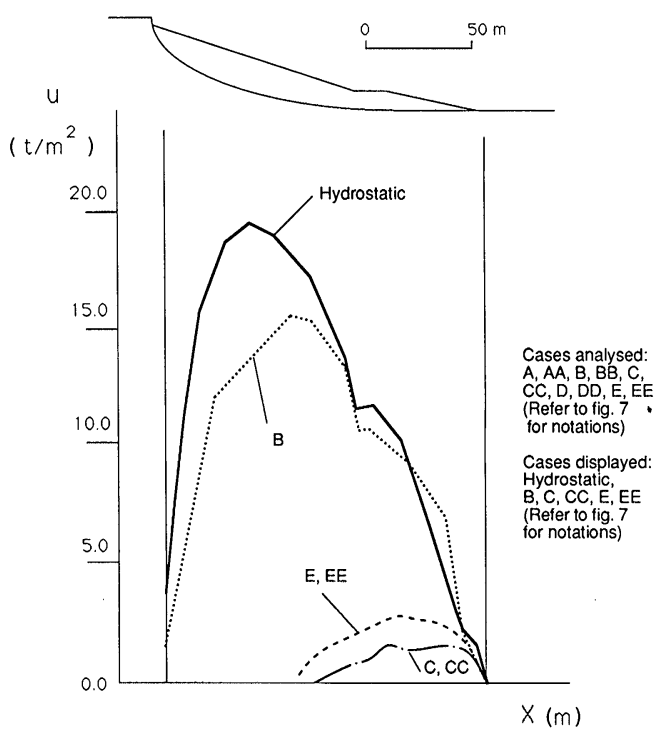

Figure 8. Pore pressures distribution on the slip surface stability factor $(\mathrm{F})$ along the whole sliding surface, without any information about the real stability conditions of different parts of the landslide body.

The usual analytical approach must be modified to consider not only the whole body but also its significant parts.

In other words the method adopted must correspond to the mechanism of formation and development of landslides, and not merely provide for a global safety factor. If such an approach is adopted one may be able to explain the first occurrence of a landslide as well as its reactivation or extension by retrogression.

In the lower part of the slip surface of Nakatayema landslide the calculated pore pressures are not so high as in the Italian landslides, but no doubt higher than the hydrostatic datumdistribution.

In these conditons a method proposed by Sauer (1983) was used which considers different blocks of the landslide separately as well as together. Sauer applied this method mainly for understanding the mechanism of formation of some retrogressive landslides along a river in Canada and in order to compare back calculated strength parameters to those obtained in laboratory tests. He considered the landslide as a chain (or group) of blocks of which the lowest falied first. He started from the lower block of the chain and added always a new block, proceeding from the toe to the upper part of the slope.

The authors of the present work took into consideration the principle of this kind of analysis, but they had to make two fundamental assumptions.

Firstly, the lower part of the landslide body, the one affected by a high pore pressure field (Fig. 9), was considered to be the block 1 of the chain although it was not a separate block in reality.

Secondly, it was assumed that over the whole length of the slip surface, only one value of shear strength angle $\left(\phi_{\mathrm{m}}\right)$ was operative. This assumption could be justified for a slip surface which is predominantly planar in shape in one kind of homogeneous material.

Therefore, as a first step, the stability of block I was analysed (assuming $\mathrm{c}=0$ and $\mathrm{F}=1$ ) and a first value of $\phi_{\mathrm{m}}$ was obtained (mobilized shear strength angle). Since the landslide body was divided in only two blocks, successively the stability of the whole landslide body was analysed (block $1+$ block 2 ) and a new value of $\phi_{\mathrm{m}}$ was obtained.

As previously stated, the analysis was performed both for the B pore pressure distribution and for the hydrostatic datum-distribution (Fig. 10).

For the B distribution the calculated $\phi_{\mathrm{m}}$ value for block 1 was about the same as that for blocks 1 and 2 together i.e. approximately 26 degrees.

For the reference distribution (the hydrostatic) the values of $\phi_{\mathrm{m}}$ for block 1 and the whole body (block 1 and 2) were different to a significant extent.

For the landslide body as a whole the hydrostatic distribution is more severe than the $\mathrm{B}$ distribution. Therefore, it is not surprising that the hydrostatic distribution leads to a high value of mobilized friction

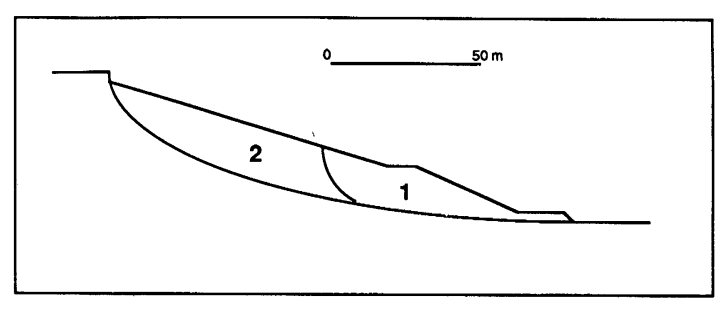

Figure 9. Cross section showing potential landslide mass considered as two blocks for purposes of analysis. 
angle for $F=1$. However based on this high average angle, the factor of safety of the lower block would have been 1.48 which is inconsistent with the failure mechanism for this type of landslide: Therefore, it would seem reasonable to conclude that the backcalculated values from $\mathrm{B}$ distribution are realistic. In these stability studies the value of cohesion has been assumed to be zero for the sake of comparison only. However, if data were available similar comparisons could be made for any value of the cohesion $c$.

\section{Conclusions}

The result of study using a numerical model of seepage shows that variation of coefficient of permeability with depth leads to high pore water pressures at the toe of the slope for the case history discussed here.

This result fits in very well with the results of research previously carried out in respect of four Italian landslides. Moreover, it is very significant considering the observed data on many landslides in Japan which show that high values of pore pressures, in excess of hydrostatic ones, exist in the lower parts of many slopes.
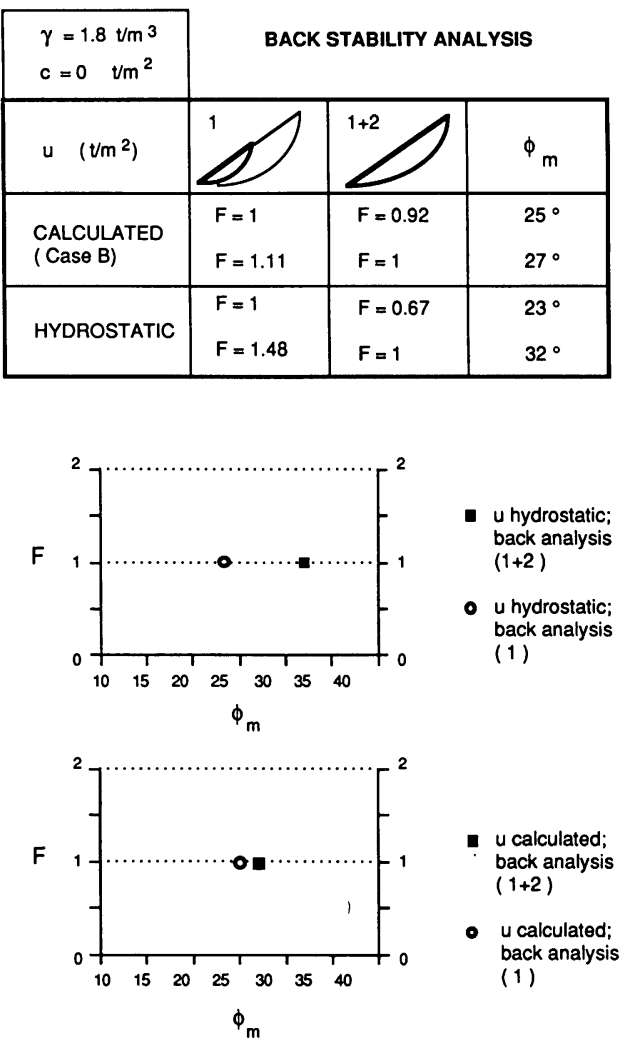

Figure 10. Results of back stability analysis

The study takes into account more than one possible variation in coefficient of permeability with depth. The cases considered give widely different distributions of pore water pressures along the slip surface. The lack of any mesurement of pore pressures along the slip surface prevented the authors from establishing directly which could be the actual pore pressures distribution among the calculated ones. Even the hydrostatic pore pressures distribution may be still the worst along some parts of the sliding surface, for the Nakatateyama landslide, however, it is significant that values of pore pressures higher than the hydrostatic ones are predicted near the toe of the slope on the basis of observed values of permeability based from pumping tests.

The results of the back stability analysis seem to indicate that the predicted pore pressures, in contrast to the hydrostatic ones, are critical for the stability of the slope considering the mechanism of landslide development by retrogression. The closeness of $\phi_{\mathrm{m}}$ value from analysis of block 1 to that from analysis of block 1 and 2 together may be just fortuitous since it is quite reasonable to expect variability of shearing resistance within different sections of the landslide body or of the slip surface.

To obtain more consistent results from the stability analysis it would be necessary to have the actual strength values along the slip surface.

Nevertheless, the predicted values of pore pressure suggest that a process of progressive failure may take place starting from the foot of the slope. This process would, of course, be facilitated if the angle of internal friction along the lower part of the slip surface is small in comparison to other parts of the slip surface.

The main thrust of this research has been to establish that variation of permeability with depth gives pore pressures along the slip surface which are significantly different from hydrostatic values. While the hydrostatic values are relatively small for the lower parts of the slip surfaces, they are relatively large for the upper parts. In the example studied here back-analysis for the slide body as a whole and a hydrosnatic pore pressures leads to an 
overestimate of the shear strength which is undesirable and should be avoided. This would be expected in other similar cases.

Therefore, more such studies are required. Moreover further research is needed which includes measured shear strength parameters and measured pore pressure.

\section{Acknowledgements}

First author thanks the Government of Japan for giving him the opportuniy of studying the Japanese landslides. He is indebted to prof. R. Chowdhury of University of Wollongong (Australia) for much valuable advice and useful critical discussions. He is also grateful to Mrs. M. L. Vignaroli and Mr. M. Vergoni for their technical support.

\section{References}

Angeli M.-G. "The role of anisotropic permeability on slopes instability condinions" Proc. of XI Int. Conf. on soil Mechanics and Foundation Engineering, S. Francisco, August 12-16 1985, vo1. 4, pp. 2301$2305,1985$.

Angeli M.-G., Mearini G. Tonnetti G. "Hydrogeological processes in some past-failed slopes" CNR-PAN Meeting on Progress in Mass Movement and Sediment Transport Studies, Torino, December 5-7 1984, pp. 151-159, 1984.

Angeli M.-G., Tonnetti G. "The effectiveness of in situ permeability tests" (contribution to discussion) Int. Symposium of Landslides, Toronto, September 16-21 1984, vo1. 3, pp. 103, 1984.

Angeli M.-G., Tonnetti G. "Osservazioni sul comportamento idraulico di alcuni pendii in frana" Atti XVI Conv. Naz. di Geotecnica, Bologna 14-16 Maggio 1986, vo1. 1, pp. 1-6, 1986.

Sauer E. K. "The Denholm landslide, Saskatchewan. Part II: Analysis" Canadian Geotechnical Journal, vo 1. 20, pp. 208-220, 1983.

Tonnetti G., Angeli M.-G. "Geological, kinematical and developing features of some landslides in PlioPleistocene clayey sediments of the Adriatic hilly region in Italy" IV Int. Symposium on Landslides, Toronto, September 16-21 1984, vo1. 2, pp. 221-226, 1984.

（原稿受理日 平成元年 7 月 7 日） 